\title{
Pro-oxidant-mediated hepatic fibrosis and effects of antioxidant intervention in murine dietary steatohepatitis
}

\author{
NGHI PHUNG ${ }^{1}$, NATASHA PERA ${ }^{1}$, GEOFFREY FARRELL ${ }^{2}$, ISABELLE LECLERCQ ${ }^{3}$, \\ JING YUN HOU ${ }^{1}$ and JACOB GEORGE ${ }^{1}$ \\ ${ }^{1}$ Storr Liver Unit, Westmead Millennium Institute, University of Sydney at Westmead Hospital, \\ Westmead, NSW 2145; ${ }^{2}$ ANU Medical School, Australian National University at Canberra Hospital, \\ Canberra, ACT, Australia; ${ }^{3}$ Laboratory of Gastroenterology, Department of Internal Medicine, \\ Universtité Catholique de Louvain (UCL), Brussels, Belgium
}

Received December 16, 2008; Accepted January 30, 2009

DOI: $10.3892 /$ ijmm_00000220

\begin{abstract}
The mechanistic significance of oxidative stress to fibrogenesis in the methionine and choline-deficient (MCD) diet-induced model of steatohepatitis was evaluated by antioxidant intervention, using either vitamin E or L-2-oxothiazolidine-4-carboxylate (OTC), a cysteine precursor that promotes glutathione synthesis. Significant depletion of hepatic reduced glutathione (GSH) and elevation of thiobarbituric acid reactive substances (TBARS) occurred from week 3 in association with hepatic injury in mice fed the MCD diet. Hepatic stellate cell (HSC) activation and increased collagen $\alpha_{1}$ (I) mRNA expression, together with morphologic fibrosis were evident from week 5. Vitamin E repleted GSH, reduced TBARS, steatosis, inflammation, HSC activation and collagen $\alpha_{1}(\mathrm{I})$ mRNA expression, and ameliorated fibrosis. Vitamin E did not effect the expression of either profibrogenic cytokines (transforming growth factor- $\beta 1$, connective tissue growth factor) or matrix remodeling enzymes (tissue inhibitor of metalloproteinase- 1 and -2, matrix metallo-
\end{abstract}

Correspondence to: Professor Isabelle Leclercq, Laboratory of Gastroenterology, Université Catholique de Louvain (UCL), UCL/ GAEN 5379, Avenue E. Mounier 53, 1200 Brussels, Belgium E-mail: isabelle.leclercq@uclouvain.be

Abbreviations: $\alpha$ SMA, $\alpha$ smooth muscle actin; ALT, alanine aminotransaminase; CTGF, connective tissue growth factor; GAPDH, glyceraldehyde-3-phosphate dehydrogenase; GSH, reduced glutathione; H\&E, hematoxylin and eosin; HSCs, hepatic stellate cells; MCD, methionine and choline deficient; mRNA, messenger RNA; NASH, nonalcoholic steatohepatitis; OTC, L-2-oxothiazolidine-4-carboxylate; MMP-2 and -13, matrix metalloproteinase-2 and -13 ; PCR, polymerase chain reaction; ROS, reactive oxygen species; TBARS, thiobarbituric acid reactive substances; TGFß ${ }_{1}$, transforming growth factor- $\beta 1$; TIMP-1 and -2 , tissue inhibitor of metalloproteinase-1 and -2 ; vit $\mathrm{E}$, vitamin $\mathrm{E}$

Key words: oxidative stress, lipid peroxidation, fibrosis, steatohepatitis, vitamin $\mathrm{E}$ proteinase-2 and -13). Despite repletion of hepatic GSH in OTC-supplemented mice, the initial benefit in the reduction of hepatic TBARS and inhibition of collagen $\alpha_{1}(\mathrm{I})$ mRNA expression at week 5 , failed to protect these mice from hepatic injury or fibrosis at later time points. Oxidative stress or products of lipid peroxidation mediate HSC activation and collagen gene expression directly in the MCD model of steatohepatitis. Vitamin E but not glutathione augmentation can interrupt this pathogenic process.

\section{Introduction}

Steatohepatitis not attributable to excess alcohol intake (nonalcoholic fatty liver disorder, NAFLD), initially recognized in obese or diabetic patients $(1,2)$, is currently accepted as a disorder of insulin resistance and the hepatic manifestation of the metabolic syndrome $(3,4)$. Between 15 and $30 \%$ of patients with NAFLD subjected to liver biopsy have steatohepatitis (NASH) with advanced hepatic fibrosis or cirrhosis $(3,5,6)$. The prognosis in such cases is similar to that of cirrhosis due to chronic hepatitis $\mathrm{C}$ (7). The mechanisms that mediate the transition from steatosis to fibrosing steatohepatitis are hypothesized to comprise multiple processes, in which inflammatory recruitment and lipid peroxidation are central pathophysiological associations (8-10).

We previously reported that steatohepatitis produced in rodents by feeding them a lipogenic diet deficient in both methionine and choline (MCD) is associated with profound oxidative stress and depletion of total glutathione $(11,12)$. In both rats and mice, these changes preceded the detection of hepatocellular injury, inflammation and morphologic fibrosis $(13,14)$. Oxidative stress can also be detected in livers of humans with NAFLD (15-17), being most conspicuous in association with steatohepatitis. In animal models of steatohepatitis including mice deficient in acyl-CoA oxidase (18) and methionine adenosyltransferase 1A (19), profound oxidative stress appears to be a cardinal feature. In alcoholic hepatitis, a histologically similar form of steatohepatitis, products of lipid peroxidation have been incriminated in the pathogenesis of hepatic inflammation, liver injury and fibrogenesis (20). In vitro studies provide further evidence to 
support a proposed link between products of lipid peroxidation, such as 4-hydroxynonenal and malondialdehyde, and the induction of collagen $\alpha_{1}(\mathrm{I})$ mRNA expression by hepatic stellate cells (HSCs) (21).

In addition to the increased activity of pro-oxidant pathways (such as leukocyte NADPH, and hepatocellular, mitochondrial, microsomal and peroxisomal oxidases) depletion of hepatic antioxidant defences also contributes to oxidative stress in steatohepatitis. In the MCD dietary model, deprivation of sulfhydryl amino acid precursors essential for glutathione (GSH) synthesis, contributes to the development of oxidative stress. If this is the case, provision of alternative sources of amino acid building blocks may stimulate GSH synthesis and combat oxidative damage. Intervention with antioxidant therapies is an alternative strategy, and vitamin $\mathrm{E}$ has been shown to ameliorate oxidative stress and reverse fibrosis in other experimental forms of liver disease $(22,23)$.

In an earlier study of hepatic fibrogenesis in the rat MCD diet model, we found a time course consistent with oxidative stress preceding hepatic stellate cell activation and fibrogenesis (13). Others have shown that iron loading, which exacerbates lipid peroxidation, accelerates hepatic fibrogenesis (24). We undertook the present study to characterize further the relationship of oxidative stress to fibrogenesis in the MCD diet-induced model of 'fibrosing steatohepatitis'. If oxidative stress is crucial to fibrogenesis in steatohepatitis, we hypothesized that antioxidant therapy using vitamin $\mathrm{E}$ or repletion of GSH with L-2-oxothiazolidine-4-carboxylate (OTC), a cysteine precursor, should ameliorate the development of fibrosis.

\section{Materals and methods}

Animals and diet. All protocols for animal experimentation and maintenance were approved by the Western Sydney Area Health Service Animal Ethics Committee and conformed to the highest international standards. Animals were monitored daily to ensure continued well being. Male C57/B6 mice obtained from the Animal Resource Centre (Canning Vale, Western Australia) were fed a custom-made diet rich in fat $(10 \%)$ and carbohydrates, and deficient in methionine and choline (MCD) (ICN Biomedicals Inc., Sydney, Australia; catalogue no. 960439) for periods of 3, 5 and 10 weeks. Control mice were fed the same diet, supplemented with DLmethionine $(3 \mathrm{~g} / \mathrm{kg})$ and choline $(2 \mathrm{~g} / \mathrm{kg})$. Treatment groups fed the MCD diet were supplemented with either dl- $\alpha-$ tocopherol acetate $(250 \mathrm{mg} / \mathrm{kg}$ diet $)$ or L-2-oxothiazolidine4-carboxylate (OTC) (p.o. $20 \mathrm{mmol} / \mathrm{kg}$ body wt/day) (Sigma, St. Louis, MO).

Animals ( $\mathrm{n}=5-8$ per group) were sacrificed at 3, 5 and 10 weeks under anesthesia with ketamine $(10 \mathrm{mg} / 100 \mathrm{~g}$ body weight) and xylazine $(0.4 \mathrm{mg} / 100 \mathrm{~g}$ body weight $)$. Serum was obtained by cardiac puncture, and the liver was removed for histologic, biochemical and molecular studies.

Morphologic studies. Liver histology was assessed on 5- $\mu \mathrm{m}$ paraffin sections stained with hematoxylin and eosin (H\&E) for the extent of steatosis and inflammation. Steatosis and inflammation were scored by an observer blinded to the study arm, as previously described (25). Steatosis scores were based on the percentage of hepatocytes showing lipid accumulation: $1-33 \%$ as $1,34-66 \%$ as 2 , and $67-100 \%$ as 3 . Inflammation was scored as 1 (mild), 2 (moderate) and 3 (severe). Collagen deposition was quantified in Sirius red-stained sections at week 10 using morphometry to determine the percentage (\%) of the total cross-sectional surface area occupied by collagen (Optimas v6.5 software, Media Cybernetics L.P., Silver Spring, MD, USA). As described elsewhere, 10 random fields were scanned (13). Using the same sections, the degree of fibrosis was ranked by two independent observers blinded to the study. Activated HSCs were identified in paraffin sections by immunohistochemistry using a mouse monoclonal antibody to $\alpha$ smooth muscle actin ( $\alpha$ SMA) (1:400 dilution, clone 1A4, Sigma), and visualized by avidin/biotinylated horseradish peroxidase (anti-mouse) using the mouse ABC Staining System Kit (Santa Cruz Biotechnology Inc., Santa Cruz, CA). Activated HSCs were quantified by the average number of aSMA positively stained cells excluding vascular smooth muscle cells from 10 high power fields per animal (magnification $\mathrm{x} 400$ ).

Biochemical assays. The extent of hepatocellular injury was assessed by determining the serum level of alanine aminotransaminases (ALT), measured by automated techniques within the Department of Clinical Chemistry at Westmead Hospital. GSH was determined fluorometrically (excitation $350 \mathrm{~nm}$, emission $420 \mathrm{~nm}$ ) as previously described (26). Products of lipid peroxidation in 5\% liver homogenates were determined by measuring thiobarbituric acid reactive substances (TBARS) using the method of Ohkawa (27). Activated $\mathrm{TGF}_{1}$ protein levels were estimated in $10 \%$ liver homogenates using a Duoset ELISA development system for human $\mathrm{TGF}_{1}$ (R\&D Systems, Minneapolis, MN, USA) as per the manufacturer's instructions.

PCR for cytokines and genes that regulate matrix deposition. Whole liver total RNA (5 $\mu \mathrm{g})$ was reverse transcribed using random hexamers (Promega Corp., Madison, WI), and SuperScript II RNase H Reverse Transcriptase (Gibco BRL, Melbourne, Australia). Levels of mRNA expression for collagen $\alpha_{1}(\mathrm{I})$, transforming growth factor- $\beta 1$ (TGF $\left.\beta_{1}\right)$, connective tissue growth factor (CTGF), tissue inhibitor of metalloproteinase-1 and -2 (TIMP-1 and -2) and matrix metalloproteinase-2 and -13 (MMP-2 and -13) were quantified by real-time PCR with glyceraldehyde 3-phosphate dehydrogenase (GAPDH) as invariant control. All primers and probes (Table I) were designed using Primer Express ${ }^{\mathrm{TM}}$ Software (Applied Biosystems, Foster City, CA, USA). PCR reactions and analyses were carried out using the ABI PRISM 7700 Sequence Detector and Software (Applied Biosystems) using TaqMan ${ }^{\circledR}$ fluorogenic probes (GAPDH) or SYBR Green detection (collagen $\alpha_{1}(\mathrm{I})$, TGFß $\beta_{1}$, CTGF, TIMP-1, TIMP-2, MMP-2, and MMP-13). Cycle parameters were set at $50^{\circ} \mathrm{C}$ for $2 \mathrm{~min}$, then $95^{\circ} \mathrm{C}$ for $10 \mathrm{~min}$, followed by 45 cycles at $95^{\circ} \mathrm{C}$ for $15 \mathrm{sec}$ and $60^{\circ} \mathrm{C}$ for $1 \mathrm{~min}$. Collagen mRNA expression was also assessed at week 10 by RNase protection assay as previously described (13).

Statistical analyses. Results are presented as the mean \pm standard deviation. The 2-way ANOVA and Student's t-test 

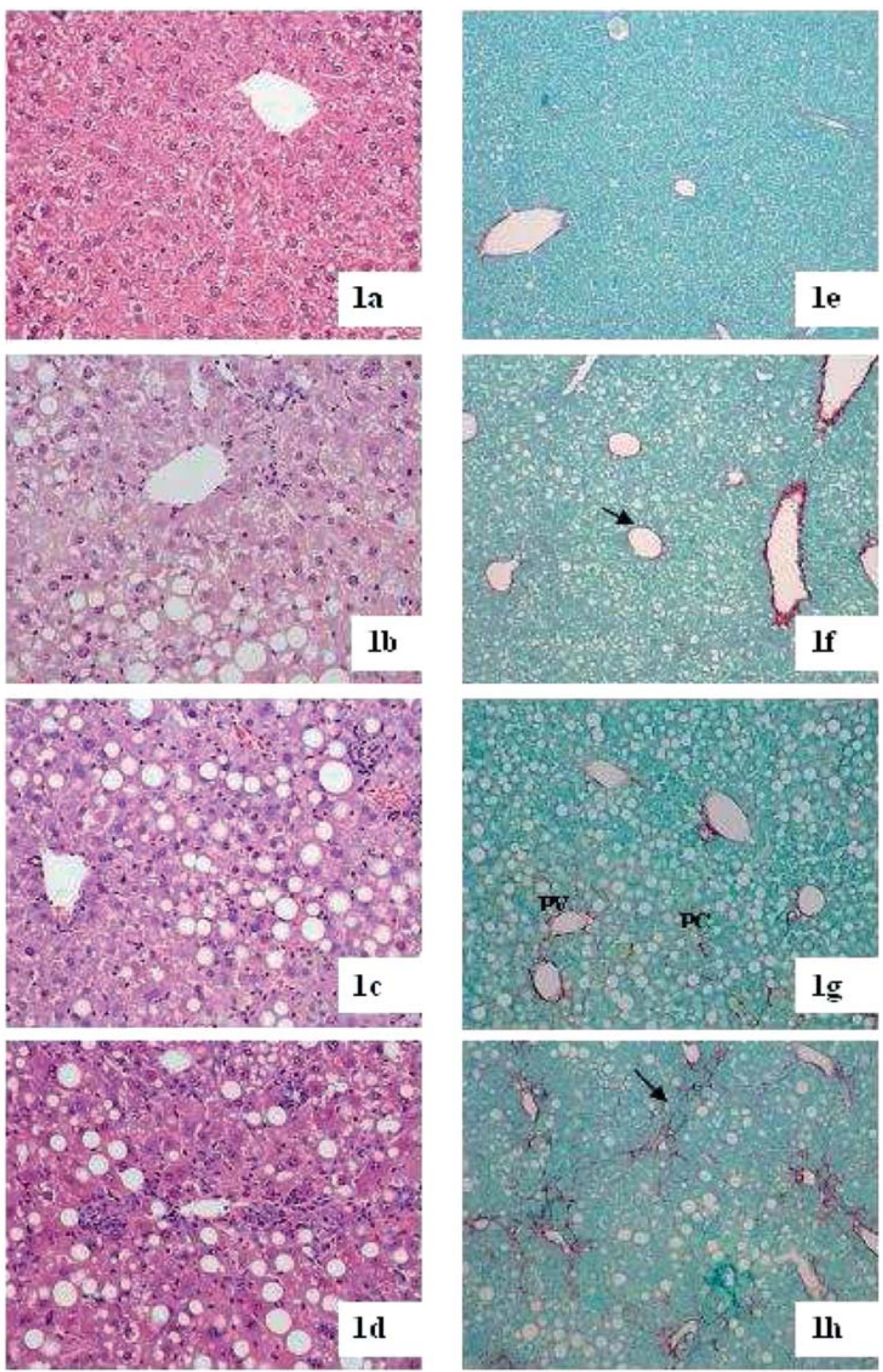

Figure 1. Temporal development of steatohepatitis and fibrosis in mice fed the MCD diet compared to controls. Compared with control (a), MCD feeding was associated with steatohepatitis at week 3 (b), which became progressively more florid and extensive at weeks 5 (c) and 10 (d) (H\&E, original magnification x200). Collagen deposition around blood vessels (arrow), stained by Sirius red, was comparable to control (e) at week 3 (f). Fibrosis initially perivenular (PV) and pericellular (PC) at week $5(\mathrm{~g})$ extended to the formation of septa (arrow) at week 10 (h) (original magnification x100).

were used to compare treatment groups. Differences were considered significant at $\mathrm{P}<0.05$.

\section{Results}

Development of fibrosing steatohepatitis in mice fed an MCD diet: Relationship to glutathione depletion, lipid peroxidation, stellate cell activation and expression of profibrogenic genes. Liver injury was evident early in the 10 week time-course study. Serum ALT levels were increased at week 3, reaching a mean of 16 times the control value by week 10 (Table II). In mice fed the control diet, liver histology remained normal throughout. By week 3, mice fed the MCD diet had developed hepatic steatosis (zone 2 and 3) and a mixed parenchymal inflammatory infiltrate. During the next 7 weeks, there was progression of steatohepatitis such that by week 5 , steatosis extended throughout the hepatic acinus, and inflammation was more severe (Fig. 1a-d; Table III). 
Table I. Primers and probes for real-time PCR.

\begin{tabular}{|c|c|c|}
\hline Gene & Accession no. & Forward $(\mathrm{F}) /$ Reverse $(\mathrm{R})$ primers/Probe $(\mathrm{P})$ \\
\hline mCollagen $\alpha_{1}(\mathrm{I})$ & ВС003198 & $\begin{array}{l}\text { F: CCTCAGGGTATTGCTGGACAAC } \\
\text { R: ACCACTTGATCCAGAAGGACCTT } \\
\text { P: 6FAM-CTTCCCGGTCAGAGAGGAGAAAGAGGCT-TAMRA }\end{array}$ \\
\hline $\mathrm{mTGF}_{1}$ & ВС013738 & $\begin{array}{l}\text { F: GCCCGAAGCGGACTACTATG } \\
\text { R: AGATGGCGTTGTTGCGGT } \\
\text { P: ACCATTAGCACGCGGGTGACCTCTTT }\end{array}$ \\
\hline mCTGF & ВC006783 & $\begin{array}{l}\text { F: ACTGCCCCTTCCCGAGAA } \\
\text { R: TCCTTGGGCTCGTCACACA } \\
\text { P: TCGCAGCATTTCCCAGGCAGCTT }\end{array}$ \\
\hline mTIMP-1 & ВC008107 & $\begin{array}{l}\text { F: CATGGAAAGCCTCTGTGGATATG } \\
\text { R: GATGTGCAAATTTCCGTTCCTT } \\
\text { P: CAAGTCCCAGAACCGCAGTGAAGAGTTTC }\end{array}$ \\
\hline mTIMP-2 & X62622 S37984 & $\begin{array}{l}\text { F: ATGGTTCTTGCGCGTGGTA } \\
\text { R: GCTTTTCAATTGGCCACAGG } \\
\text { P: TGTCAGCCTTCTTACGGGTCCTCGA }\end{array}$ \\
\hline mMMP-2 & M84324 & $\begin{array}{l}\text { F: GATACCCTCAAGAAGATGCAGAAGTT } \\
\text { R: ACATCTTGGCTTCCGCATG } \\
\text { P: CAGACAGGTGACCTTGACCAGAACACCAT }\end{array}$ \\
\hline mMMP-13 & X66473 S48798 & $\begin{array}{l}\text { F: ACTTAACTTACAGGATTGTGAACTATACTCCT } \\
\text { R: TGTCAGCAGTGCCATCATAGATT } \\
\text { P: AGGCCTTCTCCACTTCAGAATGGGACATA }\end{array}$ \\
\hline mGAPDH & M32599 & $\begin{array}{l}\text { F: GTCGTGGATCTGACGTGCC } \\
\text { R: TGCCTGCTTCACCACCTTCT } \\
\text { P: 6VIC-CCTGGAGAAACCTGCCAAGTATGATGACA-TAMRA }\end{array}$ \\
\hline
\end{tabular}

Table II. Time course of hepatic injury, oxidative stress, stellate cell activation and up-regulation of collagen $\alpha_{1}(\mathrm{I})$ gene expression in mice fed the control or MCD diet.

\begin{tabular}{llccccc}
\hline $\begin{array}{l}\text { Duration of } \\
\text { feeding }\end{array}$ & $\begin{array}{c}\text { Experimental } \\
\text { group (n) }\end{array}$ & $\begin{array}{c}\text { Serum ALT } \\
(\mathrm{U} / \mathrm{l})\end{array}$ & $\begin{array}{c}\text { Hepatic GSH } \\
(\mu \mathrm{g} / \mathrm{g} \text { tissue) }\end{array}$ & $\begin{array}{c}\text { Hepatic TBARS } \\
(\mu \mathrm{mol} / \mathrm{g} \text { tissue) }\end{array}$ & $\begin{array}{c}\text { Activated stellate cells } \\
\text { (number of } \alpha \text { SA- } \\
\text { positive HSCs/ field) }\end{array}$ & $\begin{array}{c}\text { Collagen } \alpha_{1}(\mathrm{I}) \\
\text { mRNA } \\
\text { (arbitrary units) }\end{array}$ \\
\hline 3 weeks & Control (5) & $41 \pm 52$ & $1940 \pm 108$ & $0.11 \pm 0.09$ & $0.00 \pm 0.00$ & $0.02 \pm 0.01$ \\
& MCD (5) & $380 \pm 122^{\mathrm{a}}$ & $1495 \pm 324^{\mathrm{a}}$ & $0.30 \pm 0.11^{\mathrm{a}}$ & $0.00 \pm 0.00$ & $0.02 \pm 0.01$ \\
5 weeks & Control (5) & $19 \pm 11$ & $1450 \pm 243$ & $0.19 \pm 0.02$ & $0.00 \pm 0.00$ & $0.01 \pm 0.01$ \\
& MCD (5) & $701 \pm 224^{\mathrm{a}}$ & $842 \pm 82^{\mathrm{a}}$ & $5.05 \pm 2.86^{\mathrm{a}}$ & $2.60 \pm 1.9^{\mathrm{a}}$ & $0.30 \pm 0.11^{\mathrm{a}}$ \\
10 weeks & Control (6-7) & $35 \pm 21$ & $1780 \pm 339$ & $0.19 \pm 0.03$ & $0.00 \pm 0.00$ & $0.10 \pm 0.08$ \\
& MCD (6-8) & $548 \pm 518^{\mathrm{a}}$ & $910 \pm 95^{\mathrm{a}}$ & $4.36 \pm 2.45^{\mathrm{a}}$ & $1.84 \pm 1.83^{\mathrm{a}}$ & $0.48 \pm 0.32^{\mathrm{a}}$ \\
\hline
\end{tabular}

Data are expressed as the mean $\pm \mathrm{SD}$. ${ }^{\mathrm{a}} \mathrm{P}<0.05$ relative to control values.

In mice fed the MCD diet, hepatic glutathione levels were significantly depleted compared with control mice at week 3 (Table II), with a further decline to $50 \%$ of controls by week 10. As previously reported $(12,25)$, hepatic TBARS levels were elevated from week 3 , rising to 26 -fold that in controls at week 5, and remaining elevated to week 10 (Table II).
Activated HSCs were evident in liver sections stained for aSMA from week 5 of MCD feeding but were not noted at week 3 ; they were seen predominantly around inflammatory foci and steatotic hepatocytes (Fig. 2b). Activated HSCs were not found in controls for the entire period (Fig. 2a; Table II). Activation of the HSCs was associated with significantly up- 



Figure 2. $\alpha$-smooth muscle actin ( $\alpha$ SMA) immunostaining in liver sections from mice fed the MCD or control diet at week 10. (a) Mice fed the control diet showed $\alpha$ SMA expression, indicated by the brown staining confined to the portal tract fibroblasts (not shown) and central vein (arrow). (b) In mice fed the MCD diet for 10 weeks, $\alpha$ SMA was expressed in the HSCs in the hepatic lobule (arrows), distributed around steatotic hepatocytes and inflammatory foci. (c) $\alpha$ SMA expression by HSCs was not evident in mice supplemented with vitamin E, but on the other hand was still abundant in animals supplemented with OTC (arrows) (d) (original magnification $\mathrm{x} 400$ ).

Table III. Effects of vitamin E and L-2-oxothiazolidine-4carboxylate on steatosis and inflammation in mice fed the MCD or control diet.

\begin{tabular}{llll}
\hline $\begin{array}{l}\text { Duration } \\
\text { of feeding }\end{array}$ & \multicolumn{1}{c}{$\begin{array}{c}\text { Experimental } \\
\text { group (n) }\end{array}$} & Steatosis $^{\mathrm{a}}$ & Inflammation $^{\mathrm{a}}$ \\
\hline 5 weeks & Control (5) & $0.00 \pm 0.00$ & $0.00 \pm 0.00$ \\
& MCD (5) & $2.80 \pm 0.45^{\mathrm{b}}$ & $3.00 \pm 0.00^{\mathrm{b}}$ \\
& MCD and vit E (5) & $2.80 \pm 0.45^{\mathrm{b}}$ & $2.60 \pm 0.55^{\mathrm{b}}$ \\
& MCD and OTC (5) & $2.20 \pm 0.54^{\mathrm{b}}$ & $2.60 \pm 0.55^{\mathrm{b}}$ \\
10 weeks & Control (7) & $0.00 \pm 0.00$ & $0.00 \pm 0.00$ \\
& MCD (7) & $2.29 \pm 0.76^{\mathrm{b}}$ & $2.45 \pm 0.19^{\mathrm{b}}$ \\
& MCD and vit E (8) & $1.50 \pm 0.53^{\mathrm{bc}}$ & $1.25 \pm 0.46^{\mathrm{bc}}$ \\
& MCD and OTC (8) & $2.00 \pm 0.93^{\mathrm{b}}$ & $2.13 \pm 0.64^{\mathrm{b}}$ \\
\hline
\end{tabular}

${ }^{a}$ Steatosis and inflammation were scored as described in Materials and methods. Data are expressed as the mean $\pm \mathrm{SD}$. ${ }^{\mathrm{b}} \mathrm{P}<0.05$ relative to control values. ${ }^{c} \mathrm{P}<0.05$ relative to values for MCD diet fed mice.

regulated expression of collagen $\alpha_{1}$ (I) mRNA from week 5, values being 22-fold higher than controls (Table II), and maintained thereafter. Hepatic fibrosis was evident in Sirius red-stained sections at week 5 ; the distribution was perivenular, intralobular pericellular (chicken wire) and periportal (Fig. 1e-g). By 10 weeks, septal fibrosis was conspicuous (Fig. 1h).
MCD feeding induced minor changes in $\mathrm{TGF}_{1}$ expression (Table IV). CTGF mRNA expression, downstream from $\mathrm{TGF}_{1}$, was up-regulated compared to controls at week 10 of MCD diet feeding (Table IV). Likewise, TIMP-1, TIMP-2, MMP-2, and MMP-13 mRNA were up-regulated by week 10 (Table IV).

Effects of vitamin E and L-2-oxothiazolidine-4-carboxylate supplementation on liver injury, hepatic GSH and lipid peroxides. We designed intervention experiments over 5 and 10 weeks to test the proposal that oxidative stress plays a causal role in fibrosis development. For these experiments, we chose vitamin E (vit E), a lipid soluble free radical scavenger, and OTC, a glutathione precursor, for their different modes of action.

Vit E supplementation reduced steatosis and inflammation compared to the MCD diet fed mice at week 10, although not at the earlier time point (Fig. 3a-b; Table III). In contrast, OTC supplementation did not significantly reduce steatosis or inflammation (Fig 3c; Table III).

At weeks 5 and 10 of dietary feeding, both vit E and OTC supplementation repleted GSH, compared to mice fed the MCD diet alone $(\mathrm{P}<0.05)($ Fig. 4). At week 5, vit E supplementation also reduced hepatic TBARS levels by $75 \%$ $(\mathrm{P}<0.05)$, though this protective effect appeared to diminish by week 10 (Fig. 5). OTC supplementation did not significantly alter TBARS levels (Fig. 5).

Effects of vitamin E and L-2-oxothiazolidine-4-carboxylate supplementation on hepatic fibrosis. Supplementation with 
Table IV. Effects of vitamin E and $L$-2-oxothiazolidine-4-carboxylate on $\mathrm{TGF}_{1}$, CTGF and matrix remodeling enzymes in mice fed the MCD or control diet for 10 weeks.

\begin{tabular}{lccccccc}
\hline $\begin{array}{l}\text { Experimental } \\
\text { group (n) }\end{array}$ & $\begin{array}{c}\text { TGFß } \\
\text { mRNA } \\
\text { (arbitrary } \\
\text { units) }\end{array}$ & $\begin{array}{c}\text { Activated } \\
\text { TGFß } \beta_{1} \text { protein } \\
(\mathrm{pg} / \mathrm{mg})\end{array}$ & $\begin{array}{c}\text { CTGF } \\
\text { mRNA } \\
\text { (arbitrary } \\
\text { units) }\end{array}$ & $\begin{array}{c}\text { TIMP-1 } \\
\text { mRNA } \\
\text { (arbitrary } \\
\text { units) }\end{array}$ & $\begin{array}{c}\text { TIMP-2 } \\
\text { mRNA } \\
\text { (arbitrary } \\
\text { units) }\end{array}$ & $\begin{array}{c}\text { MMP-2 } \\
\text { mRNA } \\
\text { (arbitrary } \\
\text { units) }\end{array}$ & $\begin{array}{c}\text { MMP-13 } \\
\text { mRNA } \\
\text { (arbitrary } \\
\text { units) }\end{array}$ \\
\hline Control (6) & $23 \pm 6$ & $26 \pm 4.6$ & $7 \pm 3$ & $8 \pm 7$ & $11 \pm 2$ & $12 \pm 3$ & $3 \pm 1$ \\
MCD (7) & $29 \pm 12$ & $20 \pm 1.9^{\mathrm{a}}$ & $41 \pm 20^{\mathrm{a}}$ & $37 \pm 25^{\mathrm{a}}$ & $23 \pm 8^{\mathrm{a}}$ & $33 \pm 16^{\mathrm{a}}$ & $30 \pm 23^{\mathrm{a}}$ \\
MCD and vit E (6) & $30 \pm 12$ & $20 \pm 3.5^{\mathrm{a}}$ & $46 \pm 17^{\mathrm{a}}$ & $22 \pm 15$ & $28 \pm 7^{\mathrm{a}}$ & $25 \pm 7^{\mathrm{a}}$ & $30 \pm 30^{\mathrm{a}}$ \\
MCD and OTC (7) & $57 \pm 22^{\mathrm{a}}$ & $20 \pm 1.5^{\mathrm{a}}$ & $41 \pm 30^{\mathrm{a}}$ & $40 \pm 25^{\mathrm{a}}$ & $36 \pm 16^{\mathrm{a}}$ & $42 \pm 29^{\mathrm{a}}$ & $51 \pm 17^{\mathrm{a}}$ \\
\hline
\end{tabular}

Data are expressed as the mean $\pm \mathrm{SD}$. ${ }^{\mathrm{a}} \mathrm{P}<0.05$ relative to the respective control values.
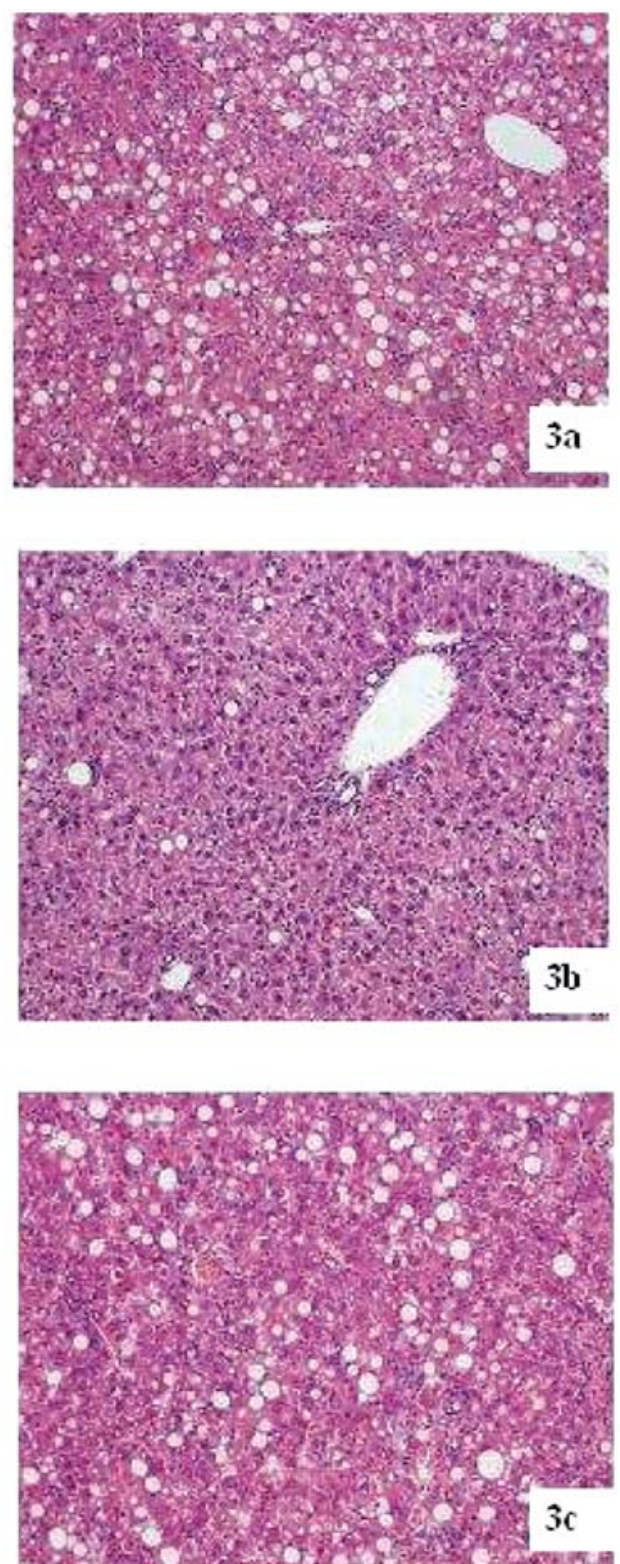

Figure 3. Effects of antioxidant therapy on liver histology in mice fed the MCD or control diet at week 10. Mice fed the MCD diet developed florid steatosis and foci of necroinflammation (a, see also Fig. 1d). Inflammatory foci and steatosis were reduced by vitamin E supplementation (b) but not by OTC (c). (H\&E sections, original magnification x100).

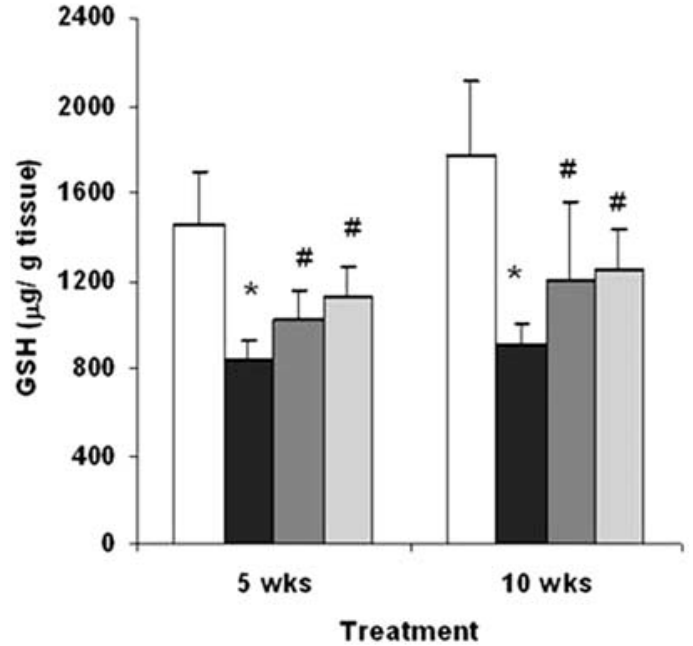

Figure 4. Effect of the MCD diet with or without antioxidant supplementation on hepatic GSH. Hepatic GSH levels in mice fed the MCD (black bars) or control diet (white bars) for 5 or 10 weeks. Supplementation with vitamin E (dark gray bars) and OTC (light gray bars) repleted hepatic GSH. Data are expressed as the means \pm SD for $n=5-8$ per group. ${ }^{*} \mathrm{P}<0.05$ compared with mice fed the control diet. ${ }^{\#} \mathrm{P}<0.05$ compared to mice fed the MCD diet.

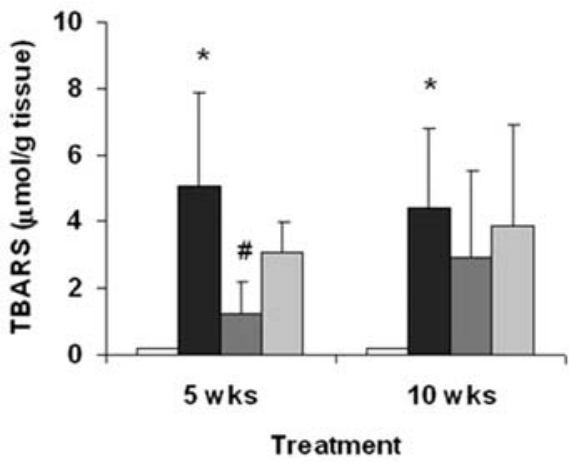

Figure 5. Effect of the MCD diet with or without antioxidant supplementation on TBARS. TBARS levels in mice fed the MCD (black bars) or control diet (white bars) for 5 or 10 weeks. Compared to mice fed the MCD diet alone, supplementation with vitamin E (dark gray bars) reduced TBARS levels. OTC supplementation (light gray bars) did not significantly alter TBARS levels, although a trend for reduction was noted at week 5. Data are expressed as the means \pm SD for $n=5-8$ per group. ${ }^{*} \mathrm{P}<0.05$ compared with mice fed the control diet. ${ }^{"} \mathrm{P}<0.05$ compared to mice fed the MCD diet. 


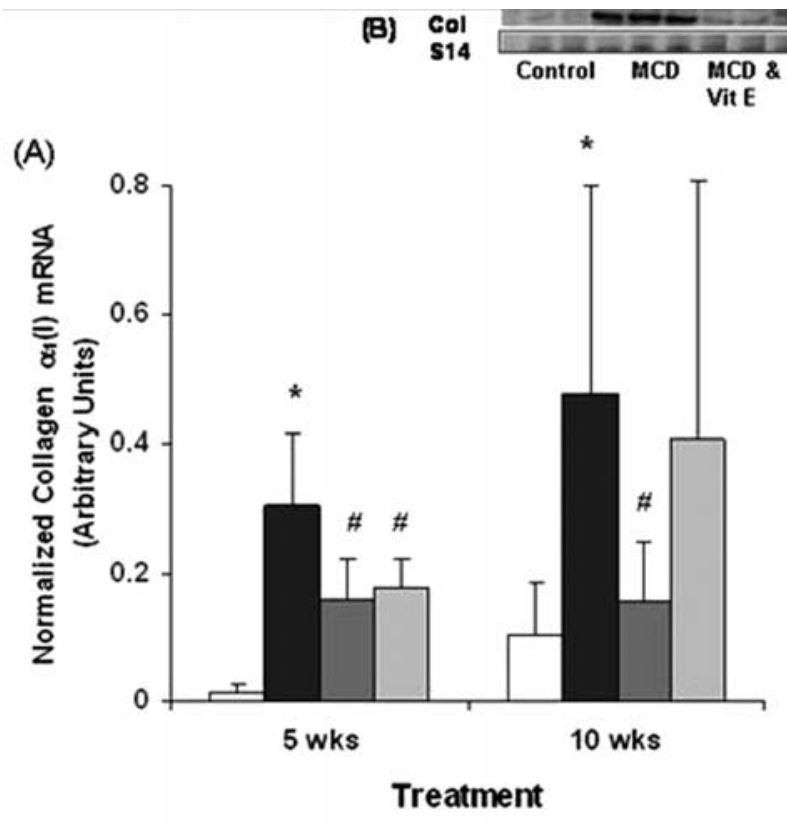

Figure 6. Effect of the MCD diet with or without antioxidant supplementation on collagen $\alpha_{1}$ (I) mRNA expression. Collagen $\alpha_{1}(\mathrm{I})$ mRNA expression in mice fed the MCD (black bars) or control diet (white bars) for 5 or 10 weeks by real-time PCR (A) and by RNase protection assay at week 10 (B). Compared to mice fed the MCD diet alone, supplementation with vitamin $\mathrm{E}$ (dark gray bars) reduced collagen $\alpha_{1}(\mathrm{I})$ mRNA expression. OTC (light gray bars) initially reduced collagen $\alpha_{1}(\mathrm{I})$ mRNA expression at week 5 , but the benefit was abolished at week 10. Data are expressed as the means $\pm \mathrm{SD}$ for $\mathrm{n}=5-8$ per group. ${ }^{*} \mathrm{P}<0.05$ compared with mice fed the control diet. ${ }^{\#} \mathrm{P}<0.05$ compared to mice fed the MCD diet.

vit E reduced HSC activation (Fig. 2c), significantly suppressed hepatic collagen $\alpha_{1}(\mathrm{I})$ mRNA expression at both week 5 and 10 (Fig. 6), and fibrosis was ranked less severe in mice supplemented with vit E compared to MCD diet fed mice at week 10 (Fig. 7B). These findings were confirmed on morphometric analysis for collagen in Sirius red-stained sections (Fig. 7A). In contrast, OTC failed to inhibit HSC activation (Fig. 2d). Thus, while collagen $\alpha_{1}$ (I) mRNA expression was inhibited at week 5 , this effect was lost by week 10 (Fig. 6), Also, expression of profibrogenic genes and fibrosis were similar whether MCD animals received or not OTC (Table IV) (Fig. 7A and B).

Despite the reduction in collagen $\alpha_{1}(\mathrm{I})$ mRNA expression and collagen deposition at week 10 in mice supplemented with vit $\mathrm{E}, \mathrm{mRNA}$ levels of profibrogenic genes, including $\mathrm{TGF} \beta_{1}$, CTGF, TIMP-1, TIMP-2, MMP-2 or MMP-13 were not significantly altered, although there was a trend for reduction in TIMP-1 mRNA expression (Table IV).

\section{Discussion}

This study provides support for a role for oxidative stress in mediating hepatic fibrosis in steatohepatitis resulting from intake of a lipogenic MCD diet. In mice fed the diet, a decline in hepatic GSH and elevation of TBARS occurred at the onset of liver injury, preceding HSC activation and upregulation of collagen $\alpha_{1}(\mathrm{I})$, profibrogenic cytokines, metalloproteinases and their inhibitors, and morphologic evidence of progressive hepatic fibrosis. Vit E antioxidant therapy suppressed steatosis, inflammation, HSC activation, collagen $\alpha_{1}$ (I) mRNA up-regulation and fibrosis, in association with lower TBARS and higher GSH levels. In contrast, the reduction in collagen $\alpha_{1}(\mathrm{I})$ mRNA at week 5 with OTC was not sustained despite repletion of hepatic GSH to levels comparable with those noted with vit E supplementation.

In vitro vit E supplementation of cultured human fibroblasts and HSCs $(28,29)$ reduces lipid peroxidation and



(A)

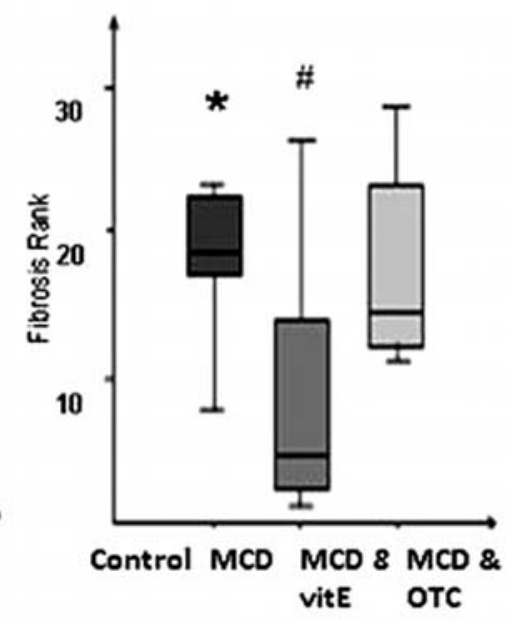

(B)

Figure 7. Effects of the MCD diet, with or without antioxidant supplementation on fibrosis at week 10. (A) Image analysis of fibrosis based on collagen deposition stained by Sirius red in mice fed the MCD (black bars) or control diet (white bar) and mice fed the MCD diet supplemented with vitamin E (dark gray bars) or OTC (light gray bars) (data expressed as the means \pm SD). (B) Fibrosis ranking based on collagen deposition stained by Sirius red (data expressed as a box and whisker plot. The bar within each column represents the median value, the upper and lower borders of the box are the quartiles, and the whiskers (error bars) at the extremities indicate the 10 th and 90 th percentiles). All data for $\mathrm{n}=7-8$ per group. ${ }^{*} \mathrm{P}<0.05$ compared with mice fed the control diet. " $\mathrm{P}<0.05$ compared to mice fed the MCD diet. 
inhibits collagen gene up-regulation. Similar effects have been noted in animal models of fibrosis associated with iron overload and carbon tetrachloride $\left(\mathrm{CCl}_{4}\right)$. In gerbils with iron overload (23), vit E supplementation for 4 months reduced lipid peroxidation, and this blocked up-regulation of collagen $\alpha_{1}(\mathrm{I})$ gene expression and progression to cirrhosis. Likewise, in rats with chronic iron overload (30), vit E reduced lipid peroxidation over 4,8 and 14 months, and at the later time point, reduced hepatic hydroxyproline content; however, there was no evidence of collagen $\alpha_{1}(\mathrm{I})$ mRNA up-regulation in this model. In $\mathrm{CCl}_{4}$-induced liver injury in rats, vit $\mathrm{E}$ prevented oxidative liver damage and ameliorated hepatic fibrosis (22). The benefit of vit E in human NASH has been variable. Vit E and $\mathrm{C}$ treatment improved fibrosis scores without reductions in inflammatory changes in a randomized, placebo controlled study (31). In another study, treatment with vit E decreased steatosis, but the improvements observed in inflammation and fibrosis were not significant (32). Cumulative data to date therefore, are insufficient to either support or refute the benefits of antioxidant therapy for patients with NASH, in part due to limited studies with histological outcomes $(33,34)$.

While vit $\mathrm{E}$ had a dramatic impact on both lipid peroxidation and fibrosis in our model, its efficacy as an antioxidant appeared to diminish over time. This may reflect the consumption of vit $\mathrm{E}$ by the ongoing pro-oxidants generated during MCD diet feeding. However, in a pilot study, higher doses of vit E (480 mg/kg diet) for 5 weeks did not indicate any additional benefit (data not shown). The antioxidant capacity of vit $\mathrm{E}$ is dependent on the recycling of oxidized $\alpha$ tocopherol by co-antioxidants such as ubiquinol-10 which may have become depleted by week 10 in the present report, thereby limiting its beneficial effects (35). This limitation in antioxidant capacity may explain the variable benefits of vit $\mathrm{E}$ in patients with NASH $(31,32)$.

OTC, while protective against oxidative liver injury in other systems, was insufficient in the MCD dietary model of steatohepatitis. Thus, unlike vit E, OTC did not reduce hepatic steatosis or inflammation; its ability to suppress lipid peroxidation and collagen $\alpha_{1}(\mathrm{I})$ gene expression appeared transient and incomplete, and was unable to sustain protection against fibrosis beyond week 5 . In rats exposed chronically to alcohol, OTC reduced inflammation, NF- $\mathrm{B}$ activation and serum AST levels (36). In the MCD model, the protective effect of OTC treatment was potentially limited by the reduced availability of glutathione peroxidase which catalyzes the hydrolysis of hydrogen peroxide by GSH. Both cytosolic and mitochondrial glutathione peroxidase are significantly reduced in steatotic livers (37), thereby limiting the efficacy of anti-fibrotic strategies aimed primarily at GSH repletion. In addition, we noted loss of mitochondrial integrity by week 10 of MCD diet feeding (38), and this could potentially result in decreased GSH transport into the mitochondrial compartment.

Data from this study suggest that amelioration of fibrosis occurs only when there is sufficient protection from lipid peroxidation. Oxidative stress appears to mediate fibrogenesis directly during MCD diet feeding, since activated $\mathrm{TGF} \beta_{1}$ protein levels were not increased. The critical role of TGFß in fibrogenesis is well known (39), but there is evidence that it is not an obligate requirement. Other mechanisms for fibrogenesis independent of $\mathrm{TGF} \beta_{1}$ have been reported, including CTGF- (40) and interleukin 13 (IL-13)- (41) dependent pathways, the former being inducible by oxidative stress (42) and dexamethasone (43). Thus, IL-13 null mice showed almost complete abrogation of fibrosis following Schistosoma mansoni infection, without alterations in $\mathrm{TGF}_{1}$ production (41). Disruption of the $\mathrm{TGF} \beta_{1}$ signaling cascade did not affect IL-13 mRNA expression or prevent fibrosis (41). Likewise, fibrosis in bile duct ligated rats is not completely inhibited by abolishment of TGFß signaling with soluble TGFß type II receptors, and fibrosis still occurs in response to $\mathrm{CCl}_{4}$ in $\mathrm{TGF}_{1}$ gene-deleted knockout mice $(44,45)$. A plausible mechanism for these TGFß-independent pro-oxidantmediated fibrogenic effects involves hydrogen peroxide. Hydrogen peroxide enhances the binding of the CCAAT/ enhancer binding protein- $\beta(\mathrm{C} / \mathrm{EBP} \beta)$ complex to the collagen $\alpha_{1}$ (I) promoter, thereby activating HSCs and inducing collagen $\alpha_{1}(\mathrm{I})$ mRNA expression (46). Co-administration of neutralizing anti-TGFß $\beta_{1}$ antibodies failed to abolish the up-regulation of collagen $\alpha_{1}$ (I) in response to acetaldehyde (46).

The role of TGFß in matrix remodeling has been well documented (39). However, in Schistosoma mansoni infection and cell culture studies, activation of TIMP-1 and -2 occurs through processes other than TGFß involving IL-13, IL-1ß, IL-6, IL-11, dexamethasone and prostaglandin E2 (41,48-50). In our study, up-regulation of TIMPs and MMPs is consistent with observations in fibrotic human liver (51) and other models of fibrosis induced by $\mathrm{CCl}_{4}(52)$, Schistosoma mansoni infection (41) and lipopolysaccharides (53). These results differ from other studies where downregulation of MMP-2 was shown to be concurrent with HSC and TIMP-1 activation (54).

To our knowledge, the molecular mechanisms by which vit E protects against hepatic fibrosis have not been characterized in terms of the genes associated with matrix remodeling. In a study of $\mathrm{CCl}_{4}$-induced liver injury, TIMPs but not MMPs were down-regulated during spontaneous resolution of fibrosis with a resultant increase in interstitial collagenase activity (55). In our study, the mRNA expression of the metalloproteinases and their inhibitors were not altered by vit $\mathrm{E}$ supplementation despite amelioration of fibrosis, although there was a trend for reduction in TIMP-1 mRNA expression in vit E-treated mice.

In conclusion, the results of this intervention study indicate that peroxides participate in hepatic fibrogenesis associated with a nutritional form of steatohepatitis. The antifibrotic effects of vit $\mathrm{E}$ were independent of the expression of profibrogenic cytokines or transcriptional effects on genes involved with matrix remodeling, but may instead be more directly mediated via suppression of HSC activation and transcription of matrix secreting genes like collagen $\alpha_{1}(\mathrm{I})$.

\section{Acknowledgements}

The authors acknowledge the contribution of Professor Pauline Hall for reviewing the histological sections. This study was supported by Project Grants 153899 and 107293 from the Australian National Health and Medical Research Council (NHMRC), and the Robert W. Storr Bequest of the 
University of Sydney. Dr Nghi Phung was an NHMRC Medical Postgraduate Research Scholar.

\section{References}

1. Zelman S: The liver in obesity. Arch Intern Med 90: 141-156, 1958.

2. Catlin R: Liver dysfunction after intestinal bypass. JAMA 236: 1693-1694, 1963.

3. Chitturi S, Abeygunasekera S, Farrell G, Holmes-Walker J, Hui J, Fung $\mathrm{C}$, et al: NASH and insulin resistance: insulin hypersecretion and specific association with the insulin resistance syndrome. Hepatology 35: 373-379, 2002.

4. Marchesini G, Bugianesi E, Forlani G, Cerrelli F, Lenzi M, Manini R, et al: Nonalcoholic fatty liver, steatohepatitis, and the metabolic syndrome. Hepatology 37: 917-923, 2003.

5. Bacon B, Farahvash M, Janney C and Neuschwander-Teri B: Nonalcoholic steatohepatitis: an expanded clinical entity. Gastroenterology 107: 1103-1109, 1994.

6. Diehl AM, Goodman Z and Ishak KG: Alcohol-like liver disease in nonalcoholics. A clinical and histologic comparison with alcohol-induced liver injury. Gastroenterology 95: 1056-1062, 1988

7. Hui J, Kench J, Sud A, Farrell G, Byth K, Hall P, et al: Long term outcomes of cirrhosis in nonalcoholic steatohepatitis compared with hepatitis C. Hepatology 38: 420-427, 2003.

8. Day CP and James OF: Steatohepatitis: A tale of two 'hits'? Hepatology 114: 842-845, 1998.

9. Chitturi S and Farrell G: Etiopathogenesis of nonalcoholic steatohepatitis. Semin Liver Dis 21: 27-41, 2001

10. Angulo P and Lindor K: Nonalcoholic fatty liver disease. J Gasterol Hepatol 17: S186-S190, 2002.

11. Weltman MD, Farrell GC and Liddle C: Increased Cyp2E1 expression in a rat nutritional model of hepatic steatosis with inflammation. Gastroenterology 111: 1645-1653, 1996.

12. Leclercq I, Farrell G, Field J, Bell D, Gonzalez F and Robertson G: Cyp2E1 and Cyp4A as microsomal catalysts of lipid peroxides in murine nonalcoholic steatohepatitis. J Clin Invest 105 1067-1075, 2000

13. George J, Pera N, Phung N, Leclercq I, Hou J and Farrell G: Lipid peroxidation, stellate cell activation and hepatic fibrogenesis in a rat model of chronic steatohepatitis. J Hepatol 39: 756-764, 2003

14. Robertson G, Leclercq I and Farrell GC: Nonalcoholic steatosis and steatohepatitis II. Cytochrome P-450 and oxidative stress. Am J Physiol Gastrointest Liver Physiol 281: G1135-G1139, 2001.

15. Sanyal A, Campbell-Sargent C, Mirshahi F, Rizzo W, Contos M, Sterling R, et al: Nonalcoholic steatohepatitis: Association of insulin resistance and mitochondrial abnormalities. Gastroenterology 120: 1183-1192, 2001.

16. Seki S, Kitada T, Yamada T, Sakaguchi H, Nakatani K and Wakasa K: In situ detection of lipid peroxidation and oxidative DNA damage in non-alcohol fatty liver diseases. J Hepatol 37: $56-62,2002$

17. MacDonald G, Bridle K, Ward P, Walker N, Houglum K, George $\mathrm{D}$, et al: Lipid peroxidation in hepatic steatosis in humans is associated with hepatic fibrosis and occurs predominantly in acinar zone 3. J Gasterol Hepatol 16: 599-606, 2001

18. Fan CY, Pan J, Yeldandi AV, Rao MS and Reddy JK: Steatohepatitis, spontaneous peroxisome proliferation and liver tumors in mice lacking peroxisomal fatty acyl-CoA oxidase. Implications for peroxisome proliferator-activated receptor alpha natural ligand metabolism. J Biol Chem 273: 15639-15645, 1998.

19. Lu S, Alvarez L, Huang Z, Chen L, An W, Corrales F, et al: Methionine adenosyltransferase 1 A knockout mice are predisposed to liver injury and exhibit increased expression of genes involved in proliferation. Proc Natl Acad Sci USA 98 5560-5565, 2001

20. Misra UK, Bradford BU, Handler J and Thurman RG: Chronic ethanol treatment induces $\mathrm{H}_{2} \mathrm{O}_{2}$ production selectively in pericentral regions of the liver lobule. Alcohol Clin Exp Res 16: 839-842, 1992

21. Parola M, Pinzani M, Casini A, Albano E, Poli G, Gentilini A et al: Stimulation of lipid peroxidation or 4-hydroxynonenal treatment increases procollagen alpha 1 (I) gene expression in human liver fat-storing cells. Biochem Biophys Res Commun 194: 1044-1050, 1993.
22. Parola M, Leonarduzzi G, Biasi F, Albano E, Biocca ME, Poli G, et al: Vitamin E dietary supplementation protects against carbon tetrachloride-induced chronic liver damage and cirrhosis. Hepatology 16: 1014-1021, 1992.

23. Pietrangelo A, Gualdi R, Casalgrandi G, Montosi G and Ventura E: Molecular and cellular aspects of iron-induced hepatic cirrhosis in rodents. J Clin Invest 95: 1824-1831, 1995.

24. Mackinnon M, Clayton C, Plummer J, Ahern M, Cmielewski P, Ilsley A, et al: Iron overload facilitates hepatic fibrosis in rat alcohol/low-dose carbon tetrachloride model. Hepatology 21: 1083-1088, 1995

25. Ip E, Farrell G, Robertson G, Hall P, Kirsch R and Leclerq I: Central role of PPARalpha-dependent hepatic lipid turnover in dietary steatohepatitis in mice. Hepatology 38: 123-132, 2003.

26. Hissin PJ and Hilf R: A fluorometric method for determination of oxidised and reduced glutathione in tissues. Anal Biochem 74: 214-226, 1976.

27. Ohkawa H, Ohishi $\mathrm{N}$ and Yagi K: Assay for lipid peroxides in animal tissues by thiobarbituric acid reaction. Anal Biochem 95: 351-358, 1979 .

28. Houglum K, Brenner DA and Chojkier M: Inhibition of collagen gene expression by $\mathrm{dl}-\alpha$-tocopherol in cultured human fibroblasts. J Clin Invest 87: 2230-2235, 1991.

29. Nieto N, Friedman SL, Greenwel P and Cederbaum AI: CYP2E1-mediated oxidative stress induces collagen type 1 expression in rat hepatic cells. Hepatology 30: 987-996, 1999.

30. Brown K, Poulos J, Li L, Soweid A, Ramm G, O'Neill R, et al: Effect of vitamin E supplementation on hepatic fibrogenesis in chronic dietary iron overload. Am J Physiol 272: G116-G123, 1997.

31. Harrison S, Torgerson S, Hayashi P, Ward J and Schenker S: Vitamin $\mathrm{E}$ and vitamin $\mathrm{C}$ treatment improves fibrosis in patients with nonalcoholic steatohepatitis. Am J Gastroenterol 98: 2348-2350, 2003

32. Sanyal A, Mofrad P, Contos M, Sargeant C, Luketic V, Sterling R, et al: A pilot study of vitamin $\mathrm{E}$ versus vitamin $\mathrm{E}$ and pioglitazone for the treatment of nonalcoholic steatohepatitis. Clin Gastroenterol Hepatol 2: 1107-1115, 2004.

33. Lirussi F, Beccarello A, Zanette G, De Monte A, Donadon V, Velussi M, et al: Silybin-beta-cyclodextrin in the treatment of patients with diabetes mellitus and alcoholic liver disease. Efficacy study of a new preparation of an anti-oxidant agent. Diabetes Nutr Metab 15: 222-231, 2002.

34. Lavine J: Vitamin E treatment of nonalcoholic steatohepatitis in children: a pilot study. J Paediatr 136: 711-713, 2000.

35. Thomas SR and Stocker R: Molecular action of vitamin E in lipoprotein oxidation: implication for atherosclerosis. Free Radic Biol Med 28: 1795-1805, 2000.

36. Iimuro Y, Bradford B, Yamashina S, Rusyn I, Nakagami M, Enomoto N, et al: The glutathione precursor L-2-oxothiazolidine-4-carboxylic acid protects against liver injury due to chronic enteral ethanol exposure in the rat. Hepatology 31: 391-398, 2000

37. Yang S, Zhu H, Yunbo L, Lin H and Gabrielson K: Mitochondrial adaptations to obesity-related oxidant stress. Arch Biochem Biophys 378: 259-268, 2000.

38. Phung N, Farrell G, Robertson G and George J: Vitamin E but not glutathione precursors inhibits hepatic fibrosis in experimental NASH exhibiting oxidative stress and mitochondrial abnormalities. Hepatology 34: 361 A, 2002.

39. Bissell D, Roulot D and George J: Transforming growth factor $B$ and the liver. Hepatology 34: 859-867, 2001

40. Pawar S, Kartha S and Toback F: Differential gene expression in migrating renal epithelial cells after wounding. J Cell Physiol 165: 556-565, 1995.

41. Kaviratne M, Hesse M, Leusink M, Cheever AW, Davies SJ, McKerrow JH, Wakefield LM, et al: IL-13 activates a mechanism of tissue fibrosis that is completely TGF-beta independent. J Immunol 173: 4020-4029, 2004.

42. Matsuda S, Gomi F, Oshima Y, Tohyama M and Tano Y: Vascular endothelial growth factor reduced and connective tissue growth factor induced by triamcinolone in ARPE19 cells under oxidative stress. Invest Ophthalmol Vis Sci 46: 1062-1068, 2005.

43. Dammeier J, Beer H, Brauchle M and Werner S: Dexamethasone is a novel potent inducer of connective tissue growth factor expression. Implications for glucocorticoid therapy. J Biol Chem 273: 18185-18190, 1998.

44. Hellebrand C, Stefanovic B, Giordano F, Burchardt E and Brenner D: The role of $\mathrm{TGF}_{1}$ in initiating hepatic stellate cell activation in vivo. J Hepatol 30: 77-87, 1998. 
45. George J, Roulot D, Koteliansky VE and Bissell DM: In vivo inhibition of rat stellate cell activation by soluble transforming growth factor beta type II receptor: A potential new therapy for hepatic fibrosis. Proc Natl Acad Sci USA 96: 2907-2912, 1999.

46. Greenwel P, Dominguez-Rosales J, Mavi G, Rivas-Estilla AM and Rojkind M: Hydrogen peroxide: a link between acetaldehyde-elicited $\alpha_{1}(\mathrm{I})$ collagen gene up-regulation and oxidative stress in mouse hepatic stellate cells. Hepatology 31: 109-116, 2000.

47. Parola M, Muraca R, Dianzani I, Barrera G, Leonarduzzi G, Bendinelli $\mathrm{P}$, et al: Vitamin E dietary supplementation inhibits transforming growth factor beta 1 gene expression in the rat liver. FEBS Lett 308: 267-270, 1992.

48. Roeb E, Graeve L, Hoffmann R, Decker K, Edwards D and Heinrich P: Regulation of tissue inhibitor of metalloproteinases-1 gene expression by cytokines and dexamethasone in rat hepatocyte primary cultures. Hepatology 18: 1437-1442, 1993.

49. Roeb E, Graeve L, Müllberg J, Matern S and Rose-John S: TIMP-1 protein expression is stimulated by IL- 1 beta and IL-6 in primary rat hepatocytes. FEBS Lett: 45-49, 1994.

50. Roeb E, Graeve L, Müllberg J, Matern S and Rose-John S: TIMP-1 protein expression is stimulated by IL- 1 beta and IL- 6 in primary rat hepatocytes. Ann NY Acad Sci 762: 462-464, 1995.
51. Benyon R, Iredale J, Goddard S, Winwood P and Arthur M: Expression of tissue inhibitor of metalloproteinases 1 and 2 is increased in fibrotic human liver. Gastroenterology 110: 821-831, 1996.

52. Takahara T, Furui K, Funaki J, Nakayama Y, Itoh H, Miyabayashi C, Sato H, et al: Increased expression of matrix metalloproteinase-II in experimental liver fibrosis in rats. Hepatology 21: 787-795, 1995.

53. Corbel M, Theret N, Caulet-Maugendre S, Germain N, Lagente V, Clement B and Boichot E: Repeated endotoxin exposure induces interstitial fibrosis associated with enhanced gelatinase (MMP-2 and MMP-9) activity. Inflamm Res 50: 129-135, 2001.

54. Knittel T, Kobold D, Saile B, Grundmann A, Neubauer K, Piscaglia F, et al: Rat liver myofibroblasts and hepatic stellate cells: different cell populations of the fibroblast lineage with fibrogenic potential. Gastroenterology 117: 1205-1221, 1999.

55. Iredale JP, Benyon C, Pickering J, McCullen M, Northrop M, Pawley S, et al: Mechanisms of spontaneous resolution of rat liver fibrosis. Hepatic stellate cell apoptosis and reduced hepatic expression of metalloproteinase inhibitors. J Clin Invest 102: 538-549, 1998. 